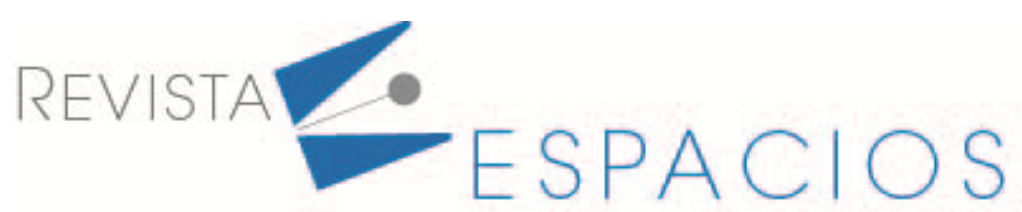

\title{
Cooperative learning: on the issue of national and international application experience
}

\section{Aprendizaje cooperativo: sobre la cuestión de la experiencia en aplicaciones nacionales e internacionales}

\author{
DEREVIANCHENKO, Elena A. ${ }^{1}$ \\ MARTYNOVA, Yulia V. ${ }^{2}$ \\ MESHCHERIAKOVA, Larisa V. ${ }^{3}$ \\ TEBENKOVA, NATALIA G. ${ }^{4}$
}

\begin{abstract}
The article presents a comparative analysis of the method of collective mutual learning and the Singapore educational technology. Organizational, methodological and technological features of learning in replaceable pairs are considered. Examples of horizontal and vertical methods of interaction between students are given. An analysis of Singapore EdTech has been made which has a set of structures that make it possible to organize the classroom in a different way. In the conclusion it is proved that both presented methods with different intensities can be integrated into the traditional teaching system, bringing into it a different structure of interpersonal communication of participants in foreign language classes.

Key words: foreign language communicative competence, method of collective mutual learning, Singapore educational technology, national educational practice

\section{Resumen}

El artículo presenta un análisis comparativo de la forma colectiva de enseñar y la tecnología educativa de Singapur. Están examinadas las características organizativas, metodológicas y .tecnológicas de la enseñanza de alumnos en parejas que cambian. Se dan ejemplos de métodos de interacción horizontal y vertical entre los estudiantes. También se analiza la tecnología educativa de Singapur, que cuenta con un conjunto de estructuras que permiten organizar el espacio de estudios de una manera diferente. En conclusión, se comprueba que ambos métodos presentados pueden ser integrados en el sistema de enseñanza tradicional con diferente intensidad, aportando una estructura de comunicación interpersonal de los participantes en las clases de lengua extranjera.

Palabras clave: competencia comunicativa en lenguas extranjeras, forma colectiva de enseñar, tecnología educativa de Singapur, práctica educativa nacional
\end{abstract}

\footnotetext{
${ }^{1}$ PhD, Associate Professor. Faculty of Foreign Languages. Omsk State Pedagogical University. Russian Federation. Email: barlen@yandex.ru

2 PhD, Associate Professor. Faculty of Foreign Languages. Omsk State Pedagogical University. Russian Federation. Email: julia79zavgorodneva@gmail.com

${ }^{3} \mathrm{PhD}$, Associate Professor. Faculty of Foreign Languages. Omsk State Pedagogical University. Russian Federation. Email: mescheryakovalarisa@gmail.com

${ }^{4} \mathrm{PhD}$, Associate Professor. Faculty of Foreign Languages. Omsk State Pedagogical University. Russian Federation. Email: limonovanatalia@yandex.ru
} 


\section{Introduction}

The problem of implementing a communicative approach in teaching foreign languages has not lost its relevance for several decades both in Russian educational practice and abroad. This is evidenced by the numerous works of researchers and practicing teachers devoted, first of all, to the issues of correct purpose setting - the definition and taxonomic description of the expected subject results. Formulated in the everyday consciousness of teachers, parents, students themselves, the social order "one must be able to communicate in a foreign language" is being transformed today in the professional environment into a very detailed document, for example, of the Council of Europe "Common European Framework of Reference for Languages: Learning, Teaching, Assessment" (CEFR, 2020), or in a detailed list of metasubject, subject, personal results, universal educational actions, which is presented in the Russian federal educational standard of the basic and profile levels in a foreign language (FSES, 2014), where the ultimate purpose of training is in the foreign language communicative competence. Speech activity has been prepared, linguistic aspects are disclosed in detail, the mechanisms of speech perception and speech production in a foreign language, etc., have long been considered, but the problem of readiness to support communication in a foreign language often remains unresolved. Thus, the main task of a foreign language teacher is to create conditions in which students will have to constantly use a foreign language as a means of communication. In this regard, it becomes obvious that it is necessary to search for specific tools-technologies that will allow in educational conditions to create communication situations close to natural, to involve students in communication through the implementation of their own communicative intentions.

Currently, Russian and foreign schools actively use the innovative Singapore educational technology (Singapore EdTech), which involves increasing the level of development of communicative competence and motivation of the studied material of students through the organization of productive interaction in the systems "student student", "student - teacher". Based on the structures of interaction, the training structures of the Singapore educational technology have a communicative orientation, suggesting a joint choice of solving certain communication problems. (Pang, 2018)

Despite the increasing popularity of this technology, it would be advisable for modern teachers to take into account the experience of teaching in cooperation already available in Russian practice, namely, the method of collective mutual learning (MCML) (A. Rivin, V. Dyachenko, A. Granitskaya and others).

The purpose of this work is to identify the potentials of the technologies under consideration, as well as opportunities for their productive combination, aimed at creating conditions favorable for communication in a foreign language in the learning process.

\section{Methodology}

To achieve this purpose, we consider it appropriate to define the following theoretical and methodological foundations of the article:

- a competence-based approach that reveals the essence of targets in modern linguodidactics and educational practice as a set of cognitive and reflexive-activity components of foreign language communicative competence and allows us to consider the entire educational process as a joint communicative activity of a teacher and students;

- a comparative approach that intensifies intercultural cross-scientific dialogue in the research community in order to search for adequate solutions to professional pedagogical problems and allows to reveal the potential of pedagogical borrowings for national educational practice. 
We will carry out a comparative analysis of the established practices - the method of collective mutual learning (MCML) (Russian Federation) and the Singapore educational technology (Singapore EdTech) (Singapore) - on the basis of criteria reflecting, on the one hand, the conceptual foundations, and on the other, which, in our opinion, is more important, the field of practical application of the named didactic methods for solving problems of teaching communication in a foreign language.

\subsection{Criterion base}

The criterion base for comparative research includes

- a didactic concept;

- the specifics of building interpersonal communication in foreign language classes;

- requirements for changes in the traditional educational process.

At the same time, by the traditional educational process, we understand the existing system of teaching a foreign language, including the traditions of didactic interaction "teacher - student - educational material", the established rules of interaction and everyday routines in the classroom.

To understand the specifics of interpersonal communication in a foreign language lesson, we will give specific techniques from educational practice for the implementation of the considered teaching methods.

\section{Results}

Attempts to overcome the monological nature of teaching and there by modernize the classroom system have been made for a long time, for example, in the 19th - 20th centuries: Monitorial System (Madras System, or Lancasterian System), the Dalton plan, the brigade-laboratory training system in the Soviet Union and many others appeared and functioned quite successfully. The disadvantages that arose during their implementation were significant: the lack of a systematic presentation of educational information, the diminution of the role of the teacher against the background of an overestimation of the educational capabilities of students, the recognition of the method of independent work as universal and, as a consequence, the appearance of a low level of student learning. Therefore, after a short-term popularity, these innovations left the mass educational practice.

\subsection{The method of collective mutual learning (MCML)}

The method of collective mutual learning ( $M C M L)$ of A. Rivin, outwardly very similar to the brigade or Lancasterian System, became in the 20-30s of the twentieth century a successful option for overcoming those shortcomings: the students worked in pairs and very rarely, no more than $20 \%$ of the total time, in groups. Study pairs are not constant participants in communication, but are constantly changing, turning into pairs of a shift composition - replaceable pairs. When working in replaceable pairs, tasks are divided into all members of the microgroup, each interviews each, each responds to each - this is how a situation of collective interaction of all participants in the work arises. We emphasize that the main unit of interaction is precisely couples formed from children of different ages and different levels of training in the subject, thus, educational and self-educational groups are formed within the school.

A. Rivin acted as a practicing researcher, trying to make the student more productive and at the same time relieve the teacher. At the same time, he proceeded not from some already known theory, but from his own experience. Personal experience and all previous practice convinced the teacher that the student quickly and qualitatively assimilates only new information which immediately after receiving has been applied in practice or transfered 
to others. The student applies and explaines the new material to others until he or she masters new knowledge or skill to perfection. (Zakharov, K, 2017)

The didactic concept of collective learning activity in the Soviet Union and in modern Russia is based on the ideas of L. Vygotsky, who believed that mental functions: voluntary attention, thinking, logical memory, will, etc., are formed initially in the collectively distributed joint activity of people, and only then these functions turn into functions of individual activity. In his opinion, thinking is born only from demand - an external impulse triggers internal processes. Proceeding from this, L. Vygotsky formulated the concept of the child's mental development through the social (collective) to the individual, which proves that the formation of such mental functions and qualities of the child's personality as thinking, attention, will, memory and others is impossible only through his individual activity, joint collective activity of the child with his peers and with adult teachers is also necessary. Moreover, joint activities should precede individual ones. Thus, the environment in which the child finds himself in the process of educational collective work is really favorable for the all-round development of the personality. (Vygotsky, L, 2005)

Considering the organizational, methodological and technological features of $\mathrm{MCML}$ in replaceable pairs, we note that the implementation of this method of teaching is based on learning technologies in cooperation, which can be conditionally divided by the way of interaction of participants into horizontal and vertical.

Building interaction in the "horizontal plane" presupposes mutual learning of students with approximately the same level of formation of educational and communicative competencies. As an example, we will cite the basic for MCML method of A. Rivin "Paragraph-by-paragraph study of the text" (Dyachenko, V, 1991), which we used to develop students' communicative reading skills with full and selective understanding, as well as to develop speaking skills, for example, on the material of the topic "Environmental Protection". For its implementation, the class is offered several subtopics within the framework of a general problem ("Water and air pollution", "Changing the forest ecosystem", "Human industrial activity as a factor of environmental pollution", "Human agrarian activity as a factor of soil depletion and desertification", etc. ), which are studied in the classroom at the same time, as a basis, students are offered the texts of popular science articles, each no more than one page in length. It is necessary to prepare several (3-5) articles for one subtopic. Students are given the task: "Read the article on your subtopic, formulate its main idea, highlight the necessary secondary details, prepare a paragraphby-paragraph retelling of the material for your friend." During the lesson, new pairs are constantly formed, working on different or identical, depending on the task set by the teacher, texts in which the students retell the material to each other, answer the questions of a friend on each fragment of the text. To avoid disruption in pairing, students working on the same article are given the same color coding, for example. To work out a large number of subtopics for each student, a "route sheet" is drawn up with color-coded partners with whom he or she must work. At the end of the subtopics, students gather in small groups to talk over the ideas they have typed and formulate the content for one subtopic, which is later presented in the class.

The organization of vertical mutual learning is possible among schoolchildren with different levels of training, when one student is ahead of the other on a specific, for example, grammatical topic. Then student 1 becomes a teacher in relation to student 2 , and he, in turn, being ahead of student 3 , turns into a teacher for him. The whole class builds a vertical hierarchy - a "ladder", where everyone simultaneously acts as both a teacher and a student. "Teachers" introduce "students" to the grammatical rule, check the exercises performed, comment on mistakes. All together are preparing for the current or intermediate control (exam), which allows you to identify the effectiveness of the built interaction. Such interaction contributes to the organization of productive independent work of schoolchildren, aimed primarily at eliminating gaps and errors in the use of language material. 
The examples given do not exhaust all the modifications of work in replaceable pairs, there can be found and actively practiced the following options: the technology of interchange of tasks according to M. Mkrtchyan, the technology of teaching reading according to M. Bulanovskaya, the Murmansk technology, V. Dyachenko's technologys, "Rivin's reverse method", Rivin - Bazhenov's technology, the technology of students' work on questionnaires, etc. All of them can serve as the basis for rebuilding the traditional - monologue - teaching system and transforming it into a truly communicative one. Such researchers and educational practitioners as $A$. Granitskaya, V. Dyachenko convincingly and technologically demonstrated in their works the transition from group interaction to collective learning interaction. (Dyachenko, V, 1991)

Summarizing what has been said, we emphasize that mutual learning in replaceable pairs, without doubt, can serve as the basis for the implementation of a competence-based approach in foreign language classes, according to which the formation and development of a foreign language communicative competence of students is provided only by their inclusion in speech activity. A student, participating in the work of replaceable pairs, becomes a subject of activity - an equal speech partner, and not its object, and the fulfillment of any educational task naturally turns into a communication process.

In the aspect of interpersonal communication, each student is aware of himself as a significant person, since he was entrusted to teach and control his friends. Thus, in addition to the actual subject results, the teacher of a foreign language contributes to the implementation of the educational aspect of his studies aimed at the development of the student's personality: the building of a creative attitude to communication and the development of soft-skills, the readiness for self-management and, ultimately, the development of selfawareness and creation prerequisites for the development of a mature personality.

Promoting interpersonal communication, developing the student's personality through his interaction with peers, teaching teamwork skills - the ideas of cooperative learning laid down by the authors in the innovative Singapore educational technology, undoubtedly echoes the concept of a collective learning method we have considered, but they cannot be identified.

\subsection{The Singapore educational technology (Singapore EdTech)}

The Singapore educational technology (Singapore EdTech), which is familiar today to almost every teacher in the world, is based on the ideas of cooperative learning, practical training, the concept of the advanced role of learning in personality development (zones of proximal development according to L. Vygotsky (Vygotsky, L, 2005), which arose at the beginning of the last century, and became widespread and thanks to such philosophers and psychologists as D. Dewey, K. Levin, M. Doitsch, J. Piaget, L. Vygotsky.

The concept of this type of education, in contrast to the method of collective mutual learning, provides for the combination of various forms of organizing the educational and cognitive activity of students: from individual to group, but does not rebuild the entire educational process into a new system of interaction, remaining within the framework of the traditional school. The communicative orientation and novelty of classes is achieved by the constantly changing composition of pairs and groups, and clear instructions for interaction with various partners (partner in the face, shoulder partner, etc.) optimize the use of time in the lesson and intensify the entire process of learning a foreign language.

Undoubtedly, an attractive advantage of Singapore technology is an impressive set of structures that allow a teacher to organize the class space differently, restructure communication, giving priority to learners, their experience, opinions and assessments, include game moments in the outline of the lesson, ensure the assimilation of the material with the help of visual supports. Understanding the essence of the new interaction, 
as well as accepting the complexity of the structures, we will try to single out their groups depending on the main task solved at one time or another in a foreign language lesson. (Pang, 2018)

One group should include educational structures aimed at increasing the level of educational motivation, for example, "Team Cheer": a short, emotionally positive exercise that can be used both at the beginning of the lesson and in the middle of it for the purpose of motivation students for productive activities in the lesson, to encourage or express gratitude. "Team Cheer" is an excellent basis not only for organizing and conducting speech and phonetic exercises, but also for enriching the dictionary with colloquial phrases, for example, even a simple greeting can be made less formal and formal:

"Long time no see! It's been ages (since I've seen you)!"

turning into a friendly gesture:

"Where have you been hiding? Top of the morning to you!"

filling the meeting with humor:

"Hello, stranger!" "Look who it is! Look what the cat dragged in!"

Interaction with the teacher is determined not only spatially: the entire lesson is not held at the blackboard, and desks can be freely rearranged, but also with the help of special signals that serve to implement feedback and stimulate students' reflection. This group of structures includes, for example, "High Five" - the teacher raises his hand, calling for silence or attracting the attention of students in order to switch them to a new step or task.

Learning structures aimed at realizing "student-student" interaction are necessary for the development of cooperation and communication, for example, our students are very fond of the "Blind Sequencing" technique, the essence of which is to jointly assemble a single puzzle (picture) on the topic of the lesson. Pupils do not stay silent, they constantly communicate with each other: dividing the fragments of the picture equally, the children alternately describe what is depicted on their piece, without showing it to the others. This is how schoolchildren determine the correct, in their opinion, arrangement of elements, laying them face down. After agreeing on the location, the students turn the pieces over and, if the puzzle is complete, congratulate each other on the team victory, and if not, correct their mistakes. The main rule in this exercise that the children must learn is to listen to each other without interruption.

The solution of tasks for the development of critical thinking and linguistic awareness of students is possible with the help of a special group of structures that aim students to the analysis of information presented in a written or sounding text (video materials, audio recordings), to compare different points of view on problems, to search for false and true information based on life experience. Thus, the method "Anticipation - Reaction Guide" enriches the life experience of children, teaches schoolchildren to compare points of view on the topic under study before and after performing the stimulus exercise. A text for such an assignment can be a provocative quote from the work of a famous scientist, politician, writer, etc., forcing students to think about what is important for them, for the team, for society as a whole: "Criticism may not be agreeable, but it is necessary. It fulfills the same function as pain in the human body. It calls attention to an unhealthy state of things" (by Winston Churchill). Students collect their opinions before working with a quote, then after, in the conclusion, they discuss how much their points of view have changed, what was the reason.

Structures that ensure the implementation of one of the main tasks of the school - to teach to learn - the structures of interaction "student - educational material" are similar in their preparation and implementation to the methods and technologies of the method of collective mutual learning in Russia, there are also provided routes and various kinds of designations for organizing interaction within the class, for example, the "Quiz-QuizTrade"-technique can become the basis for peer learning and peer review using handouts - cards with related 
questions. Schoolchildren, freely moving around the class, form pairs, ask and answer each other questions on the topic, react to the student's answer by praising or correcting his answer in case of mistakes.

Emotional positive response is a cornerstone in the implementation of whole Singapore education technology. Of course, when working in replaceable pairs in Russia, it is also important to maintain a favorable psychological climate, respectfully treating the partner, but the idea of PIES, in our opinion, can become an excellent basis for the development of a comfortable environment for each individual not only in the school space, but also society as a whole. Its basic principles: Positive interdependence, Individual participation, Equal responsibility, Simultaneous interaction, reflect the attitudes that regulate communication at all levels and in all spheres of activity of a modern society based on democratic values.

\section{Conclusions}

A comparative analysis of the main characteristics of the educational technologies we have considered is presented in the table.

Table 1

MCML versus Singapore EdTech: Main characteristics

\begin{tabular}{|c|c|c|c|}
\hline Criteria & Indicators & MCML & Singapore EdTech \\
\hline \multirow[b]{3}{*}{ didactic concept } & learning vector & from collective to individual & from individual to collective \\
\hline & student position & active & active \\
\hline & didactic tasks & $\begin{array}{l}\text { developing of foreign } \\
\text { language communicative } \\
\text { competence focusing on } \\
\text { the integrity of all linguistic } \\
\text { and speech components; } \\
\text { supporting motivation for } \\
\text { communication; } \\
\text { building the skills to learn }\end{array}$ & $\begin{array}{l}\text { developing of foreign } \\
\text { language communicative } \\
\text { competence focusing on } \\
\text { the integrity of all linguistic } \\
\text { and speech components; } \\
\text { supporting motivation for } \\
\text { communication; } \\
\text { building the skills to learn; } \\
\text { developing critical thinking } \\
\text { and language awarness }\end{array}$ \\
\hline \multirow{3}{*}{$\begin{array}{l}\text { specifics of building } \\
\text { interpersonal } \\
\text { communication in foreign } \\
\text { language classes }\end{array}$} & student roles & $\begin{array}{l}\text { student / teacher } \\
\text { communication partner }\end{array}$ & $\begin{array}{l}\text { student / teacher } \\
\text { communication partner }\end{array}$ \\
\hline & way of students interaction & $\begin{array}{l}\text { horizontal interaction (with } \\
\text { the same level of training); } \\
\text { vertical interaction (at } \\
\text { different levels of training) }\end{array}$ & $\begin{array}{l}\text { constant change of activity: } \\
\text { individual, group, } \\
\text { collective; changing the } \\
\text { organization of the } \\
\text { interaction space }\end{array}$ \\
\hline & psychological environment & $\begin{array}{l}\text { emotionally positive } \\
\text { critical }\end{array}$ & $\begin{array}{l}\text { emotionally positive } \\
\text { critical }\end{array}$ \\
\hline $\begin{array}{l}\text { requirements for changes } \\
\text { in the traditional } \\
\text { educational process }\end{array}$ & $\begin{array}{l}\text { restructuring of the } \\
\text { traditional system }\end{array}$ & is required & is not required \\
\hline
\end{tabular}

Source: made by authors

A comparative analysis of the named teaching methods showed that both of them with different intensities can be integrated into the traditional teaching system: the MCML deeply affects the basic didactic relationship of "teacher-student-educational material", and the Singapore EdTech is more adaptable to the traditional system. The both are building interpersonal communication of participants in foreign language classes: turning them into genuine communicants, contributing to the accumulation of communicative experience and the development of soft skills. 
In conclusion, we would like to emphasize that the method of collective mutual learning described by us and the innovative Singapore educational technology undoubtedly have much in common and are productive for the development of foreign language communicative competence. Their combination within the framework of one educational process is possible, and the choice of a suitable tool, first of all, depends on the purpose set by the teacher and students, in our case - "to speak a foreign language".

\section{Bibliographic references}

Dyachenko V.K. (1991) Cooperation in training: On the collective way of educational work: Book for a teacher. Moscow: Education.

Pang Ch., Lau J., Chong Poh Cheong, Low A., Cheong L. (2018). Socially Challenged Collaborative Learning of Secondary School Students in Singapore. Education Sciences. Retrieved from: https://www.researchgate.net/publication/322971710_Socially_Challenged_Collaborative_Learning_of_S econdary_School_Students_in_Singapore

Vygotsky L.S. (2005) Psychology of human development. Moscow: Smysl Publishing House; Eksmo.

Zakharov K.P., Gulk E.B. (2017) The stages of the formation of the method co-dialogue with Alexander G. Rivin. Scientific and technical statements SPbSPU. Humanities and social sciences. Vol. 8, No. 1. P. 55-64. DOI: 10.18721 / JHSS.8106

CEFR (2020) Common European Framework of Reference for Languages: Learning, Teaching, Assessment. Retrieved from: https://rm.coe.int/common-european-framework-of-reference-for-languages-learningteaching/16809ea0d4

FSES (2014) Federal State Educational Standard basic general education. Retrieved from: https://base.garant.ru/55170507/53f89421bbdaf741eb2d1ecc4ddb4c33/

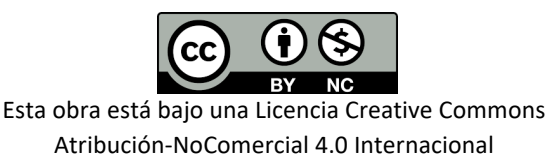

